\title{
Women in the tradition of male-female power relations in the post-divorce period: A case study in Tanjung Village, Sumenep Regency, Madura
}

\section{Perempuan dalam tradisi hubungan kekuasaan laki-perempuan pascaperceraian: Studi kasus di Desa Tanjung, Kabupaten Sumenep, Madura}

\author{
Sinta Nuriyah*, Maurelia Vidiara Auliavia, \& Nahdia Arifani \\ Department of Social Science, Faculty of Social Sciences and Law, Universitas Negeri Surabaya \\ Address: Jalan Ketintang I-8, Gayungan, Surabaya, East Java, Indonesia 60231 \\ E-mail: sinta.17040564072@mhs.unesa.ac.id
}

Article History: Received 9 November 2019; Accepted 1 February 2021; Published Online 19 March 2021

\begin{abstract}
Power relations between women and men tend to benefit men more than women. In this context, power has the meaning of influencing other parties and making them unconscious. This study aimed to determine the relationship between men and women in terms of power relations. Power is not a function of class domination based on economic control or manipulation of ideology (Marx), and it is also not based on other people's charm. Instead of perceived negatively, power should be regarded as something positive and productive. This study employs Foucault's theory of power relations, and Foucault illustrates that power is not centralized and unstructured. Power has the meaning of complex situations and strategies in people's lives. This study used a qualitative method with interview, observation, and documentation techniques. Men's power relations in Sumenep Regency to their former spouses occurred in the form of responsibility and attention, giving even the formal husband and wife relationship has ended. Power relations can be seen from verbal communication. According to Foucault, knowledge is not a theory; however, discourse is a truth built by initiators. Men continue to dominate their former spouses when they visited their ex-wife and still fulfill the responsibilities of children living costs. The situation will lead to a reluctance's sense to the ex-wives because of the effort to maintain a good relationship. The ex-wife chose to ask permission from the ex-husband when to remarry as a tradition to avoid misunderstanding in previously-related parties.
\end{abstract}

Keywords: power relations; post-divorce; tradition; men; women; children

\begin{abstract}
Abstrak
Relasi kekuasaan antara perempuan dan laki-laki cenderung lebih menguntungkan laki-laki daripada perempuan. Tujuan penelitian ini adalah untuk mengetahui hubungan antara laki-laki dan perempuan dalam hal relasi kekuasaan. Dalam konteks ini, kekuasaan memiliki arti mempengaruhi pihak lain dan membuat mereka tidak sadarkan diri. Kekuasaan bukanlah fungsi dari dominasi kelas berdasarkan kontrol ekonomi atau manipulasi ideologi (Marx), dan juga tidak didasarkan pada pesona orang lain. Alih-alih dianggap negatif, kekuasaan harus dianggap sebagai sesuatu yang positif dan produktif. Studi ini menggunakan teori hubungan kekuasaan Foucault, dan Foucault menggambarkan bahwa kekuasaan tidak terpusat dan tidak terstruktur. Kekuasaan memiliki arti situasi dan strategi yang kompleks dalam kehidupan masyarakat. Penelitian ini menggunakan metode kualitatif dengan teknik wawancara, observasi, dan dokumentasi. Relasi kekuasaan lakilaki di Kabupaten Sumenep dengan mantan istrinya terjadi dalam bentuk tanggungjawab dan perhatian, bahkan hubungan formal suami istri telah berakhir. Relasi kekuasaan dapat dilihat dari komunikasi verbal. Menurut Foucault, pengetahuan bukanlah teori; namun, wacana adalah kebenaran yang dibangun oleh pemrakarsa. Laki-laki tetap mendominasi mantan pasangannya ketika mengunjungi mantan istrinya dan tetap memenuhi tanggung jawab biaya hidup anak. Keadaan tersebut akan menimbulkan rasa enggan kepada mantan istri karena upaya untuk menjaga hubungan baik. Mantan istri memilih untuk meminta izin kepada mantan suami ketika akan menikah lagi sebagai tradisi untuk menghindari kesalahpahaman pada pihak terkait sebelumnya.
\end{abstract}

Kata kunci: relasi kekuasaan; pasca perceraian; tradisi; laki-laki; perempuan; anak 


\section{Introduction}

Madura is an island located in East Java enriched with unique cultural diversity. In Madura, Tanjung Village, Sumenep Regency, shows many phenomena on women and power relations problems. Many cases indicate a relation between power and knowledge, which is the central theme in Foucault's history throughout his academic career (Lemke 1992). Foucault had lacked in explaining specific explanations about the relations of power and knowledge. It hinders people from comprehending the connection between knowledge and power, even though there has been an explanation about each concept in his previous work (Mudhoffir 2013). Nietzsche in Susanto (2013) observes power from a relational perspective and influences this thinking, and he believes that sheer power did not produce knowledge, as there is no knowledge that neglectful to power. Thus, it should be regarded that power creates knowledge, and knowledge is a place of power (Susanto 2013).

Kamahi (2017) stated that power does not exercise the function of domination toward class-based on the economy or ideological manipulation (Marx), nor is it because of people's charisma (Weber). Power does not only come from economic ownership or physical appearance. It should be regarded positively and productively to describe complex situations in society (Kamahi 2017). Power implies domination where the relationship between controlling and being controlled existed (Kebung 2017). Power should not be understood by asking the question of 'what' power is or asking the question of 'who' has power, nor by asking must the question of 'where' power comes. Instead, power should be approached and examined by asking the question 'how' it operates. Alternatively, 'in what way' power operated; however, two concepts known in feminism are morality and loyalty, are not included in the model (Ahmad et al. 2019). Women are socially constructed as a person who should bear and raise children, loving and caring partners for husbands and take good care of parents with domesticity, obedience, passivity, and dependence (Ahmad et al. 2019).

Power relations are frequently found in men who still have related to with their former spouse in Madura. Madura identifies as a place whose people often use violence, a battle using a traditional weapon called carok. Other than that, less is known about social circumstances in Madura, including Madurese women who sometimes become the cause of carok (Dzulkarnain 2015). The throne, property, and women still believed to cause carok while most Madurese women oppose violence. Madurese women believe to be the symbol of beauty, tenderness, and toughness. Women are also an essential structural part of Madura's society (Mardhatillah 2014). They symbolize prestige and family honor; however, Madurese men are responsible for their children and ex-wives because of the obligatory feeling that bond dealers to their responsibility (Sakina \& Siti 2014).

Aside from men's responsibility (Wijaya 2012), the woman also provides love and care, as found in many widows in Madura. They keep asking their ex-husband's permission when they get married. They desperately need the blessing of their ex-husband (Khoirunnisa 2013). The phenomenon raises questions on how is the post-divorce relationship between men and women. Why does permission still necessary for women to remarry, and why should it be obtained from ex-husband? This study aims to provide answers to such questions. This research also aims to reveal the power relations of Madurese men. While the ex-wife asks permission, they also maintain the relationship on good terms (Septyaning 2012). The ex-wife also guards the rights as they tend to show respect to their ex-husbands (Fadilah 2016). Women labeled as widows still receive many judgments from the surrounding community about their attitudes and behavior (Karvistina 2011). After they hold the status of the widow, ex-wives immediately undertake the role of breadwinner. The phenomenon is common because children tend to stay with their mother after their parent's separation (Isra 2017).

Given the circumstances, women experienced dual roles for being both mother and father. They are required to balance out domestic and public roles (Nurwandi 2018). The roles have been challenging for women to undertake. Being a widow or single parent is not a wish; it is an option (Harwalina 2019). This choice is also the best decision, one made with careful consideration. For example, these considerations include meeting their needs and that of their children and facing challenges to earn a 
living and care for the children (Usman et al. 2011); however, it is not uncommon for single-parent women to have high difficulty managing time between earning a living and caring for and educating children; this results in life pressures that waste energy and time (Srimelia 2014). Ghani (2019) published about a widow in Lhokseumawe who lost her husband because of death. Since the passing of her husband, the widow lost the male power relation with five children. The woman earns a living for her children and plays a dual role for her family by selling marijuana, which she has done for three months. She sold the marijuana to pay off debts of 12 million IDR and living expenses. After being searched, officers found marijuana in her bed (Ghani 2019).

Junaidi (2017) shared another story in Sumenep, a city in Madura whose people still uphold their traditions. There was a widow with a four years old child who wanted to remarry. Her relationship with her ex-husband was also good (Junaidi 2017). His son also received care and love from his father and mother, and it can be seen from how the child changes his place of residence every month. He lived with his mother in the first month and his mother in the following month. The excellent cooperation of parents helps the children to develop reasonably. They are still acting like a functional family, and there are no power relations even though the ex-husband applies them. When the ex-wife was about to remarry, it was then discussed in the family, and permission was asked. The permission was intended for the man to bless her. Finally, the woman married again, and by the permission of her ex-husband, the woman now lives happily. Currently, the woman is pregnant with her second child by her second husband; however, the question remains on how men still have power while he has separated from his ex-wife.

Hierarchical power relations between women and men tend to be disadvantageous to women (Wijaya 2012). Relationships can occur as engendered practices (Dzulkarnain 2009). Historically, women have been subordinated and marginalized in various social institutions, and others often have a weak bargaining position to influence change. The gender division of labor has limited the mobilization of a female workforce (Mayani 2017). Efforts to reduce poverty rates hampered where men use their authority to control resources aimed at women. Development strategies need to be reaccessed by analyzing gender relations to support women's efforts in achieving equality (Dzulkarnain 2015). Ideally, women should not have to ask their ex-husbands permission because the relationship between them has been lost since the divorce; whether the ex-husband's blessing is given or not should not impact the women's lives. In Tanjung Village, women still maintain their traditions by keeping a good relationship with their ex-husband (Sakina \& Siti 2014). Therefore, men take advantage of the child's presence in exercising their power (Sarbini \& Wulandari 2010). This study aims to determine the relationship between men and women in power relations. This research will also look at how educated men think about the existing traditions.

\section{Research Methods}

This study employs qualitative methods that collected data from words or descriptions (Sugiyono 2008). Moleong in Wijaya (2002) explained that qualitative research is a research procedure that collects thousands of words, either oral or written, from a subject's behavior. This method presents the nature of the relationship between researchers and informants. Furthermore, this method is more sensitive and more adaptable to the phenomena the researcher is about to uncover. In this method, the researcher is a critical instrument that focuses on collecting data sources, which are done purposively using the snowball sampling method. In qualitative research, data supposed to be actual and contain visible and spoken reversed meaning rather than merely visible and spoken data (Patilima 2005).

Qualitative research is suitable for researchers to develop theoretical concepts (Soejono \& Abdurrahman 1999). Informants' criteria in this study were widows, regardless of their educational level. Primarily, informants should have children due to the preliminary research data stated that this tradition occurs because of children. The next informants were males from Tanjung Village with minimum education as a bachelor, which addressed whether higher education ignores the tradition. Researchers interview ten informants, and this research use a qualitative approach with the purposive sampling method. Foucault's power theory's perspective is used in this research where the power relations possessed by men in Madura are not based on violence. 
The research location was in Tanjung Village, Sumenep Regency, Madura Island. This location was chosen because ex-wives or widows in Tanjung Village asked permission from their ex-husband when they were about to remarry and kept the relationship between the two families. It becomes an interesting phenomenon to study regarding what power relations these men have. From the results of the initial observations, many perspectives encourage requests for permission before remarriage. Rationally speaking, the terminated relationship should not require permission when choosing a new path; however, in Tanjung Village, there are still deliberations between families and the introduction of new husbands for the women there. The location was selected due to the phenomenon found in the village.

Data to obtain various information about men's power relations to ex-wives using a purposive sampling technique. Determination of data sources is temporary and will develop later after field research (Wahyu 2007). Data collection starts with primary data collected directly from informants through interview techniques. Furthermore, observations were made as to a predetermined location by trying to obtain valid data. The data obtained are expected to be sustainable to answer this phenomenon and solve scientific thinking problems. Research subjects took samples using the criteria of widows aged 25-40 years, native residents of Tanjung Village, and wishing to remarry after a divorce.

The data collection technique is done by using interviews, observation, and documentation techniques. The interview technique is in which the researcher asks various questions related to the problem to be exposed. Then, selected informants will answer the researchers' questions with actual and valid data. Observation is a technique that requires researchers to directly observe the environment and analyze it when they go directly to the field. Therefore, this study will use data collection techniques using observation and interviews. The data analysis technique used in this study is qualitative data analysis, following the concept given by Miles \& Huberman (1984), which states that activities are carried out interactively and take place continuously at each stage of the research so that the data are complete and saturated. According to Miles \& Huberman in Moleong (2019), there are several analysis stages in data analysis, divided into three steps: reduction, display, verification, and conclusion.

\section{Results and Discussion}

\section{Research location profile}

Madura Island is located in East Java, consisting of several regencies, including Bangkalan, Sampang, Pamekasan, and Sumenep. The research location is in the Sumenep Regency, where the researchers found male power relations with former partners phenomenon in Tanjung Village. The village population is 3.460 people, with a male population is 1.649 , a female population is 1,811 , and consisting of 1.190 households. The residents are identified as a coastal community with prominent people's occupations are fishers and seaweed farmers, and they sell their work to village markets and outside the village. The dominant religion is Muslim — people upholding the Islam identity by having an open and friendly attitude, and the local language is Madurese with a subtle Sumenep accent (Pemerintah Kabupaten Sumenep 2020).

Sumenep Regency is famous for its local wisdom, such as the traditional Tanean Lanjhang house, commonly found in Binaba Village. The area's economic condition is relatively low; their livelihoods as farmers and fishers are insufficient to fulfill their daily needs. Thus, children's educational needs are rarely prioritized because most people perceive that education is less important for the community; education is limited to work purposes. Therefore, after a kid gets a job, their education or school will stop. Inadequate infrastructure also hinders the improvement of the quality of education in Tanjung Village.

The culture in Tanjung Village is still well preserved; for example, ludruk is an art that must take place on certain days after the Rokat Tase' event. It is an annual activity performed in every change of season. Local people will carry out a ritual, which is internalized and become a habit. In performing the ceremony, the local people will throw food and other materials into the sea (larung sesaji), and the enthusiasm of the people of Tanjung Village will be very much evident at the event; after that, they proceed to visit the Tomb of Sayid Yusuf in Talango Island. People will jointly board the ship to the final place of the rate. After the process complete, the ludruk show takes place the next day, and the 
most famous and surviving ludruk, namely Rukun Karya and Rukun Famili. Another event that usually invites enthusiasm from the Tanjung Village people and the outside community is nyadhar, which is also held on specific days after the feast; this event will provide all Sumenep specialties for sale.

\section{Power relations}

The people of Tanjung Village have highly upheld their traditions, and many of them have not been exposed to technology development. They tend to be left behind by current global circumstances that cause their culture's roots is well preserved. The people consider certain things to be sacred such as matchmaking. They also believe that refusing the person who proposed first will make them difficult to find a mate in the future. The remarrying process for divorce requires permission from various parties. In Sumenep Regency, the ex-wives have to ask permission from her ex-husband to remarry, and it uses as discourse knowledge for truth. Ex-wives think that their ex-husband still has a good relationship with them because they always support their children, which is perceived as an act of kindness of their ex-husbands. Nevertheless, with further examination, the premise will lead to a situation where men can dominate women. This domination form will lead to the attachment of the ex-wife to her ex-husband.

Our ten informants revealed that asking permission from ex-husbands is a tradition that has been done since a long time ago. Approval is required to gain blessing and forgiveness from the former spouses while still in a household relationship. As for the power relation, Madurese men in postdivorce are still responsible to their ex-wife and child. They are responsible for providing a living that causes the ex-wife to feel obligated to the ex-husband, creating an invisible power that requires the ex-wife to ask permission when she will remarry.

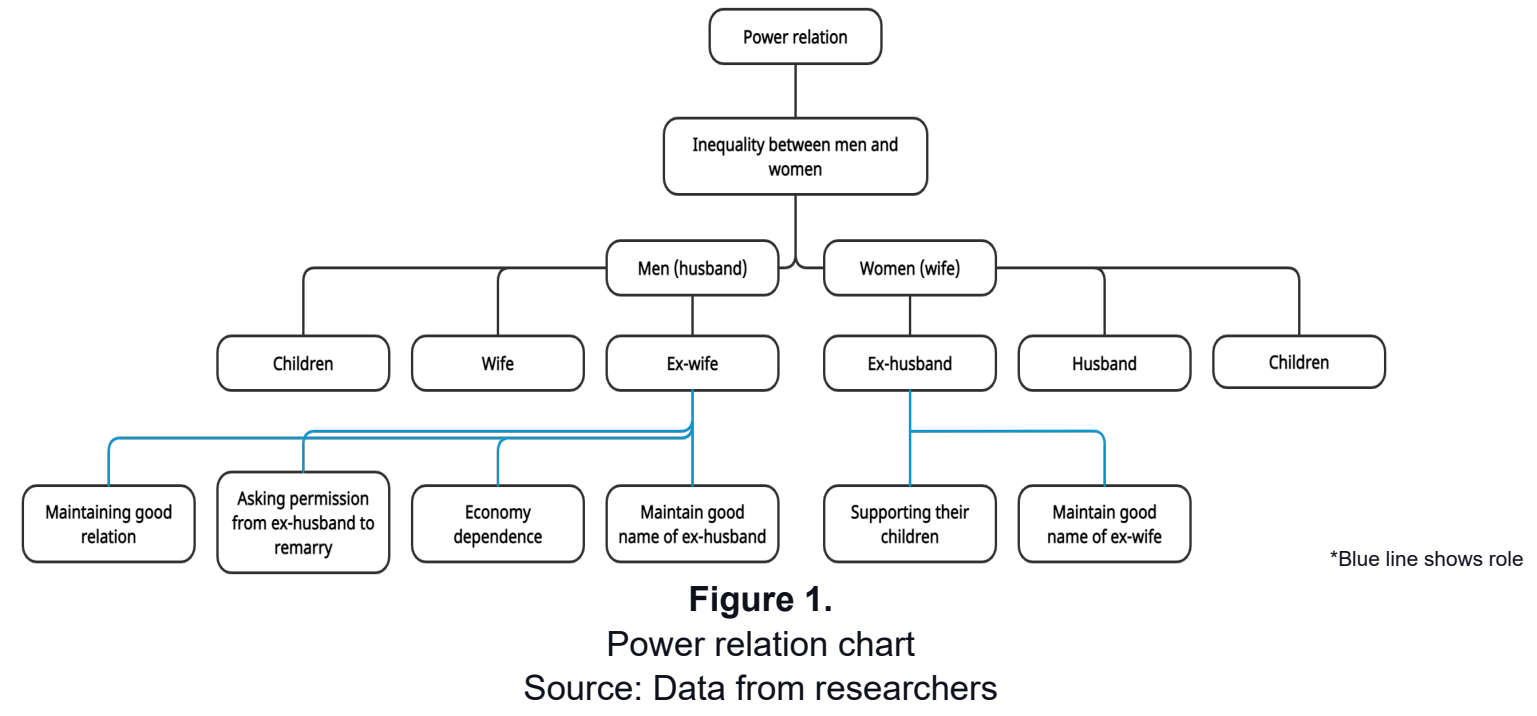

A relationship under the ruling structure causes power relations (Figure 1). This phenomenon happens naturally, and the daily process causes the higher power relations attachment. In a normal situation, women will become the power relationship axis, and limited knowledge makes women become in a sub-ordinated structure. Feminists continue to promote differences; however, a woman who becomes an ex-wife will still have an attachment to her ex-husband. The reason is the child binds them both that placed women at the bottom of the structure. Former wives in Tanjung Village will usually maintain their ex-husbands' right name, and vice versa, because both still have a sacred relationship in the marriage. Not to mention that Tanjung Village is known for its traditional observance, and the widow in Tanjung Village will try to keep a good relationship. Relationships will continue to be carried out well with ex-husbands and their relatives. Despite having decisions by both parties, harmony between families is maintained.

The ex-wife well guards the post-divorce relationship, and it is because a widow in Tanjung Village often faced economic difficulties as a single parent. For example, women would work harder after the divorce occurs. Some open shops, some sell fish in the market and even become porters in 
transporting goods. This situation happens because of increased economic demands to fulfill family alone after the divorce and did not find the husband's figure again. Children's living costs will be the wife's burden, yet the ex-husband still provides for his children; however, there will always be a moral burden for women. Not to mention the social responsibility for women when they become a wife and then become a widow, in terms of economic needs and biological needs. The bond between the two parties is the leading cause of such a phenomenon. When an ex-wife remarries, she must have permission from her ex-husband, which regards as tradition. The tradition should be upheld even if the woman is the victim. When it is withdrawn, it will lead to a patriarchal system that places women second on social structure. Even though divorce occurs, women still will not be able to free themselves from it.

Further investigating about a man after divorce, a man also keeps the right name of his ex-wife, and this happens in Tanjung Village, and the men even still feel that they are holding their women. Another task of a man is to provide for his child. Even though the relationship with the ex-wife is over, the relationship with their child still preserve. It is not surprising to find men in Tanjung Village who always provide a living to their ex-wife. His children's responsibility causes him to be dragged into the patriarchal system where his ex-wife will feel attached. Thus, the high number of widows in Tanjung Village did not remarry because she still felt comfortable with her ex-husband's attachment. The researchers asked why do informants even ask permission from their ex-husbands when they are going to remarry; YA said:

\footnotetext{
"Here is a tradition, like an obligation, so I have to ask permission from my ex-husband if I want to remarry. The reason is because it is from tradition. Yes, I also want my ex-husband and ex-in-law to be sincere. That is why this has to be sincere so that later the new marriage will be harmonious."
}

YA's answer can conclude that asking permission from the ex-husband when she is going to remarry is a traditional must-do. The ex-husband is equally sincere, making the relationship between the two still harmonious even though they will both live in a new family. It has become a habit for both parties to create a tradition, and this habit is carried out continuously and becomes something that rules must do in society. When a divorce occurs, the two parties separate on good terms and still have a relatively good relationship. When asked the same question, $\mathrm{NH}$ said:

"The problem is that from the other side also asked for permission from me. Yes, here is already a tradition, so maybe to be more sincere, right? If I say it means that there is permission and it will be calmer because I feel safe and comfortable when running a new household.”

The researchers asked about what kind of deliberations the informant take when she asks her exhusband for permission, and YAsaid:

"I do not even have a family, at least two, or if my ex-husband's parents do not exist and my parents do not exist."

$\mathrm{NH}$ also stated that asking permission from the ex-husband is very important. They considered it a tradition that must be done so that all families and related parties feel sincere and equally comfortable and maintain a good relationship through the husband and wife relationship no longer exists. In this society, it is also found that communication is essential because these two parties try to maintain a good relationship by discussing the new connection to be built (remarrying). Unlike YA and NH, NN said:

\footnotetext{
"Yes, if I want to remarry, of course I ask my ex-husband's permission first. So that everyone can give each other their blessings' marriage is something sacred and everything must be started from good things. The blessing of all parties is very important, and I can get the blessing so everything will run smoothly."
}

NN believed that marriage is something sacred. She assumes that permission is highly needed so that neither party is hurt. In addition, this is also related to feeling reluctant because of the intensity of the meeting and the provision of income which set marriage as a sacred bond. NN concerned more 
about communicating about the reluctant feeling if the ex-wife remarries and does not ask permission from the ex-husband because she has a greater intensity of meetings with the ex-husband. She would like to avoid embarrassment for not being open with her ex-husband. SS's answer was the same as YA and NH. She firmly replied that asking permission from her ex-husband when she was going to remarry was a longstanding tradition, SS said:

"Yes, it is a tradition here. I think it is a big point, in order to get the blessing of all parties."

The researchers asked about what kind of deliberation is carried out when asking permission from the ex-husband, and SS said:

"Usually just family gatherings."

The conclusion from this conversation that there is still an assumption that this happens because of a long tradition. Even though it is a good thing, however, in its actualization, women are the ones that are under pressure. They do not want to be tied down with their ex-husbands; however, economic reasons still bind to women because they need a living for their children and the next life. Like NH, HY did not say that asking permission from her ex-husband was a tradition. She only considered the need for approval for a good relationship, so neither party is hurt when a blessing has been received, HY said:

"I feel that I have good relation with my ex, so I will say well if I want to remarry, especially, right? Later, the child will have a new father, so I will talk about it well before so that they know about their real father also who the new father is, he will also live with the child. So, it's necessary to have a permit so that all parties know."

HY gave information about deliberation, what they did when they asked permission from their exhusbands; she said:

"At that time I did not have a deliberation, but immediately spoke privately with my ex if I would remarry this person and then the first ex-husband said that he was also getting married."

Asking permission is considered something that is still tied to women, which puts a good relationship as the priority. Even though the man is divorced, their child's well-being should be highly regarded. Because a marriage must be based on sincerity from all parties, there should be no party who still has not been blessed or been hurt. If the relationship is always good, it requires permission for the relationship to be harmonious. AR answered tradition, the same as YA, NH, and SS. AR, said:

"It is because of tradition, I'm from Jombang, and it seems that all the widows here will ask permission from their ex-husbands when they want to remarry. Usually after getting a letter from the court to remarry, there will be family gathering for both parties if one of them is planning to remarry, that's what I know."

In response to the question about deliberation, AR replied:

"Yes, just gather, talk, the important thing is that there are parties concerned."

The phenomenon of Tanjung Village widow who asks permission from their ex-husband when they are about to remarry is considered as knowledge in the discourse. At the same time, it is also considered as a truth. Even though the power relation does not occur because of the structure, it is still preserved. The assumption as a tradition has been recognized, even by those not native to Tanjung Village. It has become a commonplace assumption where husband and wife attachments still occur even after divorcing; however, men's dominance will be related to the patriarchal system. Women are still not free to move, especially those who live in a traditional sphere, are adamant in their customs, and always tend not to be modern; HH said:

"When it comes to asking permission, for example, if you want to get married later, that's a tradition, sis." 
AS said:

"Yes, it has become a tradition."

SS said:

"I do not know, because I am still not thinking about getting married again, it is better to take care of my child."

In response to the deliberation, SS answered:

"Family gathering from both sides."

Similar to the answer from the previous informants, the answer is still based on tradition. Do informants consider this as a phenomenon that has been carried out from generation to generation? Assumptions and answers regarding this matter concluded that the phenomenon occurs because of a tradition caused by the attachment feeling built on a relationship that persists after divorce. Madurese men are known to be responsible, kind, and still provide for their children. When this happens, it can unwittingly bind the woman and place them in a position that men can control.

From the data results, power relations occur because of knowledge used as a discourse for a truth. The existing knowledge is a good relationship measured by the intensity of the meeting between the exhusband and wife and providing vital support for their children. An ex-husband whose relationship is still good in its intensity will be considered a man with great responsibility. Therefore, then there will be a bond between the two which causes an uncomfortable feeling. It arises without realizing it as a result of the relationship that occurs.

\section{Tradition in educational perspective}

This phenomenon is only found in those (divorced husband and wife) who have children. Three female informants said she did not need to ask her ex-husband because their ex-husband's meeting intensity is different. The ex-husband often visits with the excuse of seeing the children. Those who do not have children will not meet often. It is because children are used as a tool to create feelings of attachment toward women, which causes the emergence of a tradition that requires women to ask permission from their ex-husbands in Tanjung Village.

This phenomenon is also not found for those with higher education and many informants who uphold the tradition come from high school education and below. Unlike the informants in a bachelor program and higher education, they said there was no need to carry out this tradition because the children would grow up well with education without introducing a new partner to their ex. It is the rational thinking of the educated person. They do not need the permission of their ex because their life will be different. There is no need to be tied together; the thinking of educated people expresses belief in their ex to choose the right partner for the child's survival.

Dominance is still held by men, even though there was a divorce between them; however, Tanjung Village's community has a tradition related to women. The ex-wife must ask permission from her exhusband when she is going to remarry. It is related to the data where there is a feeling of attachment men still supporting their children has been their base of a good relationship. Thus, Tanjung Village people consider this to be done so that the marriage is smooth and delicate. There is an opinion that the permission of the ex-husband is needed so that neither party is hurt. Because divorce usually occurs as a result of a problem, Tanjung Village people think, therefore, that permission is necessary so that neither party is hurt or objected. For example, the interview results with AS, a civil servant teacher in a school, related to the tradition that women ask permission from their ex-husbands to remarry, for him a child still needs love from both parents. AS stated:

"How do I maintain the child's psychology? It so happens that my child is with his mother." 
It shows that he entrusts love and affection to his ex-wife, who is the mother of his child. The relationship between the ex-husband and ex-wife maintains a good relationship, and both of them accept each other with the divorce decision they chose for a reason. So, the tradition that an ex-wife is going to remarry another man is unnecessary for him. AS said:

"It is a tradition here, however in my thinking, it is not necessary. The problem is, however, we already know the nature of the ex-wife. So it is enough just to believe that the ex-wife will choose the best new father for her child. A mother's love is greater".

Like AS, SS was a civil servant teacher at a school in Tanjung Village where he had a bachelor's degree; however, there was a difference with AS in that he did not have children with his ex-wife. Thus, it is a tradition that when the ex-wife is going to remarry, there is no need to ask the ex-husband's permission. They do not have the tools to make the two parties often meet, namely children, SS said:

\begin{abstract}
"That is usually for those who have children. Her ex-husband often visits her children, maybe you are reluctant and it's a tradition too. If I do not have children, besides, I do not really pay attention to the permission, that is, we already have our own way of life."
\end{abstract}

AA was a civil servant, holds a bachelor's degree in education, and has children from his marriage with his ex-wife. Divorce is one of the paths chosen for husbands and wives when there is a specific reason that causes them to separate; however, it is the father and mother's responsibility to keep and love the child. As did AA with his child, he still paid attention to the child's psychological condition even though she was divorced. He revealed that:

"Sometimes I visit and I invite her to take a walk."

The statement shows that a father is still providing for the child's needs of love and affection. Not only material needs; however, mental needs should be taken into account. For him, the tradition that an ex-wife who will remarry another man has to ask her ex-husband's permission is an unnecessary act. His attitude in dealing with domestic problems and his children's obligations is that children are the parents' responsibility to educate and provide affection; it does not include divorce matters from ex-wives with children's matters. As AA put it:

"I do not think it is necessary. The problem is that I, as the father, will continue to be his father. There is no ex-father right? Yes, if there is an ex-wife. So yes, if indeed my ex-wife wants to remarry, that is up to her. The most important thing is that my child's rights and obligations are fulfilled, that is enough in my opinion. No need for permits or anything, I still believe in my ex, she will give the best for my child."

\title{
Conclusion
}

Power relations are a powerful form that a person has to influence others. In the case of the postdivorce period, the affected party is the ex-wife. Tanjung Village is still classified as a region with a low economic level, and men in this village still have power relations with their ex-wives. Holding the role of husband and wife is a sacred relationship. Even divorce still places a power relation more advantageous to man. The ex-wife in Tanjung Village thinks that a man's power relationship is formed from his child's responsibility. The man party still gives love and provides for the child.

Besides, men also still maintain good relations with their ex-wives to maintain the family's harmony. Because of this power relationship, ex-wives in Tanjung Village responded by asking for permission from her ex-husband when she remarried. In addition, to being a hereditary tradition, women also want their new marriage to be sacred that no party is objected to the marriage. Therefore, asking for permission before remarriage is necessary for Tanjung Village, a situation related to men's power relations.

The phenomenon, however, of asking permission from ex-husbands was not found for those with an educational background. The meeting intensity between ex-husbands and ex-wives was so little that there was no attachment or dependence feeling. They still feel free to act without feeling embarrassed. 
Education can be a path to rational thinking. Tradition can be innovated into a more viable science for the future. The phenomenon of asking permission from ex-husbands occurs with children as a tool of male power. Men will continue to visit children so that gradually their ex-wives will feel obliged to the man, except for men with at least a bachelor's education. There is a sense of attachment, and this tradition causes women to be unconsciously bound. This tradition does not apply to former spouses who do not have children.

\section{References}

Ahmad A, Mahmood QK, Saud M, \& Mas'udah S (2019) Women in democracy: The political participation of women. Masyarakat, Kebudayaan, dan Politik 32 (2):114-122. https://doi. org/10.20473/mkp.V32I22019.114-122.

Dzulkarnain I (2009) Dinamika relasi suami istri pada masyarakat pesisir Madura (Studi terhadap manusia pasir di Sumenep). Jurnal Pamator 2 (1).

Dzulkarnain I (2015) Kuasa tubuh atas perempuan Madura. In: Prosiding Seminar Nasional Gender and Development, Madura. Madura: Puslit Gender dan Kependudukan LPPM Universitas Trunojoyo Madura.

Fadilah N (2016) Konsep diri janda akibat perceraian. Thesis, Institut Agama Islam Negeri Purwokerto, Purwokerto.

Ghani H (2019) Janda di Garut jual sabu untuk menghidupi 2 anaknya. DetikNews, 24 December. [Accessed 18 August 2020]. https://news.detik.com/berita-jawa-barat/d-4834495/janda-digarut-jual-sabu-untuk-menghidupi-2-anaknya

Isra M (2017) Janda dalam meningkatkan ekonomi keluarga di Desa Balang Taroang Kecamatan Bulukumpa Kabupaten Bulukumba. Thesis, Universitas Islam Negeri Alauddin Makassar, Makassar.

Junaidi J (2017) Jumlah janda di Sumenep bertambah setiap bulan. Koran Madura, 21 August. [Accessed 18 August 2020]. https://www.koranmadura.com/2017/08/jumlah-janda-disumenep-bertambah-setiap-bulan/.

Kamahi U (2017) Teori kekuasaan Michel Foucault: Tantangan bagi sosiologi politik. Al-Khitabah: Jurnal Komunikasi \& Penyiaran Islam 3 (3):117-133.

Karvistina L (2011) Persepsi masyarakat terhadap status janda. Thesis, Universitas Negeri Yogyakarta, Yogyakarta.

Kebung K (2017) Membaca 'kuasa' Michel Foucault dalam konteks 'kekuasaan' di Indonesia. Melintas: International Journal of Philosophy and Religion 33 (1):34-51. https://doi. org/10.26593/mel.v33i1.2953.34-51.

Khoirunnisa D (2013) Pemenuhan kewajiban mantan suami terhadap anak dan mantan istri pasca cerai. Thesis, Universitas Islam Negeri Sunan Kalijaga, Yogyakarta.

Lemke T (1992) Foucault, governmentality, and critique. Rethinking Marxism 14 (3):49-64. https:// doi.org/10.1080/089356902101242288.

Mardhatillah M (2014) Perempuan Madura sebagai simbol prestise dan pelaku tradisi perjodohan. Musawa: Jurnal Studi Gender \& Islam 13 (2):167-178. https://doi.org/10.14421/ musawa.2014.132.167-178.

Mayani LA (2017) Analisis Gender dan Transformasi Sosial karya Mansour Fakih. Yogyakarta: Insist Press.

Moleong LJ (2019) Metodologi Penelitian Kualitatif. Bandung: Remaja Rosdakarya.

Mudhoffir AM(2013) Teori kekuasaan Michel Foucault: Tantangan bagi sosiologi politik. Masyarakat: Jurnal Sosiologi 18:75-100. https://doi.org/10.7454/mjs.v18i1.3734.

Nurwandi A, Yuslem N, \& Sukiati S (2018) Kedudukan dan peran perempuan sebagai kepala keluarga menurut Hukum Islam (Studi terhadap kelompok Pemberdayaan Perempuan Kepala Keluarga-PEKKA di Kabupaten Asahan). At-Tafahum: Journal of Islamic Law 2 (1):68-85. 
Pemerintah Kabupaten Sumenep (2020) Letak Geografis. [Accessed 18 August 2020]. http://www. sumenepkab.go.id/page/letak-geografis.

Patilima H (2005) Metode Penelitian Kualitatif. Bandung: Alfabeta.

Harwalina RR (2019) Peran ganda wanita single parent dalam keluarga di Desa Kedungbanteng, Kecamatan Sukorejo, Kabupaten Ponorogo. Thesis, Institut Agama Islam Negeri Ponorogo, Ponorogo.

Sakina AI \& Siti DH (2014) Menyoroti budaya patriarki di Indonesia. Share: Social Work Journal 7 (1):71-80. https://doi.org/10.24198/share.v7i1.13820.

Sarbini W \& Wulandari K (2010) Kondisi psikologi anak dari keluarga yang bercerai. Artikel Ilmiah Hasil Penelitian Mahasiswa 2014: Universitas Jember.

Soejono A \& Abdurrahman H (1999) Metode Penelitian Suatu Pemikiran dan Penerapan. Jakarta: Rineka Cipta.

Srimelia C (2014) Peran ganda perempuan single parent dalam memenuhi kebutuhan ekonomi keluarga di Gampong Drien Tujoh Kecamatan Tripa Makmur Kabupaten Nagan Raya. Thesis, Universitas Teuku Umar Meulaboh, Aceh.

Sugiyono (2008) Metode Penelitian Pendidikan: Pendekatan Kuantitatif, Kualitatif, dan R\&D. Bandung: Alfabeta.

Susanto I (2013) Relasi Kuasa dalam Wacana Identitas. Unpublished.

Usman M, Cangara S, \& Muhammad R (2011) Kehidupan Orang Tua Tunggal (Studi Kasus Ibu sebagai Kepala Keluarga di Kelurahan Parangloe). Jurnal Pascasarjana UNY (2011):1-13.

Wijaya H (2002) Analisis Data Kualitatif Model Spradley (Etnografi). Yogyakarta: Tiara Wacana.

Wijaya IN (2012) Relasi-relasi kuasa di balik pengelolaan industri pariwisata Bali. Humaniora 24 (2):141-155. 